32 年であった。石油化学工業の基礎化学製品はエチ レンである。そしてェチレンよりスタートする膨大な 最終化学製品のらち, 最む直接的でありかつ需要も多 かったものにポリエチレンがある。ポリエチレン製造 工場も他の石油化学と同じように，わが国財閥と米国 のメーカーとの間のタイアップによるものが多かった。 工場を建設する一年ぐらい前から沪過方式に関して東 洋沪紙に相談するのは常であった。沪過器はもちろん 米国より輸入するが，それに使ら沪紙は消耗品でめり， 随時補給は国内でまかないたいからとの理由であっ た。提出されたサンプルは自分達の今まで見ない形や 性質である。第一は大きさであり，第二は合成樹脂で 加工され紙と思えないほどの強さであった。サンプル さえあれば餅は餅屋で模倣的試作には苦学がなかった。 試作品は米本国に送られチェックされるが，アメリカ 製品より優るといつも賞賛された。

\section{5 原子力産業}

戦争中に広島, 長崎に原爆投下があり, 次いで戦後 はビキ二事件で悩まされ日本国民は放射能被害を身を もって体験した。にもかかわらず，エネルギー源にそ しいわが国の将来は，原子力産業に期待せね䧇なら いとする論者も多かった。昭和 32 年茨城県東海村に 原子炉が設置され，わが国原子力産業のスタートを切 った。

東洋沪紙 (侏) は炤和 31 年原子力局加ら補助金を受け, 放射能障害防止用沪紙の研究を委託された。その成果 は第二回アイソトープ研究論文集にのせられてある。 その後, 東海村の保健に関するグループと東洋沪紙研 究所とは絶えず研究上の連絡を保ち，不測な障害発生
に関して予防安全の道を講じつつある。

\section{5. 結 語}

本稿を終るに当って, 本稿発表の動機と許可とを与 えて下さった紙パルプ技術協会專務理事名和伸氏と東 洋沪紙株式会社社長戸部晃氏に対して謝意を捧げたい。 本稿が印刷に附せられる前のナマの原稿について両氏 からは逐一に御校閲を賜わり有益な助言をいただいた。

工場勤務の最初の 6 年間に余りに重点をおき過ぎ, 従って戦中, 戦後の記事は省略に過ぎた。殊に最近の 10 年間の進歩, メンブラン沪紙, 石綿沪紙, ガラス繊 維沪紙, $\mathbf{p H}$ 試験紙の戦後の用途拡大, 各種臨床用試 験紙の開拓，イオン交換緎維沪紙，イオン試験紙（ア ルミニウム, 銅, クロム, 鉄, ニッケル, 銀) の発売 などを省かなければならなかった。

終末の余白を利用し 本稿 (I ) 中の 12 個所に 肩書 きしてあった番号に答えるため年代略譜を追記する。

石油ショック以来, 日本の諸工業がおしなべて将来 の指向を戸惑うように, 他力本願的研究資材供給メ一 カーとしてはなおさらに，目下は暗中を模索中である。

日本分析化学会の要請に応じ同会の発行する月刊紙 「ぶんせき」11月号あたりに, 沪紙の関与する「分析 化学のあゆみ」が掲載される予定がある。本稿“沪紙 生産 60 年の歩み”之重復せぬよう，むしろ 尻切れと んぼの本稿の補遺ともならばと心を配った。お読みい ただく光栄を持つならば，紙パルプ技術協会を通じて お申込下さる有志があったなら喜んで别刷を贈らせて いただきたい。

（完）

\title{
年代略譜
}

1. 紙の発明，蔡倫による 後漢時代 紀元 105 年

2. 人造絹糸の発明 Cross and Bevan (1892)

3. 毛管分析法 F. Goppelsroeder, Koll, Z., 4, 98 (1909) 伊東半治郎 薬学雑誌 59 巻 (1939)

4. 班点分析法 F. Feigle, Qualitative Analyse mit Hilfe von Tüpfelreactionen (1938) 仲野尚一日本化学会誌 70 巻 (1948)

5. ペーパークロマトグラフィ Consden, Gordon and Martin; A Partition Chromatographic Method using Paper; (1944)

6. 沪紙クロマトグラフィ 後藤秀弘 柿田八千代 日本化学会誌 63 巻 (1942)

7. 薄層クロマトグラフィ Stahl; Pharmazie, 11 (1956)

8. ペーハー試験紙 昭和 6 年発売

9. 原子力用高性能沪紙 昭和 32 年創製

10. ガラス繊維沪紙 第二次戦争中 (米国) 昭和 42 年発売 (東洋沪紙製)

11. 石英繊維製円筒沪紙 昭和 46 年

- 訂正 昭和 50 年 9 月号 p. 7 左列上より 17 行目 紙紙に関する…...沪紙に関する…… 